\title{
WPROWADZENIE
}

\section{Grzegorz SKRUKWA}

Uniwersytet im. Adama Mickiewicza w Poznaniu

Interdyscyplinarność z filarem w postaci historii wydaje się być oczywistym podejściem badawczym w przypadku badań obszarowych. W USA, w państwach Europy Zachodniej, w Polsce, a także na samym obszarze byłego ZSRR, istnieją ośrodki naukowo-badawcze: instytuty, centra i redakcje czasopism naukowych zajmujące się badaniami obszarowymi terytorium byłego ZSRR. W nazwie mają czasem „wschodni”, czasem „wschodnioeuropejski” „wschodnioeuropejski i azjatycki”, „słowiański”, „postradziecki”, „europejski i azjatycki”. Maja na ogół charakter interdyscyplinarny, z różnym udziałem historyków, politologów, antropologów kulturowych, socjologów, badaczy kultury itd.

Kwestią dyskusyjną jest, czy i na ile dziedzictwo wynikające z przynależności do 1991 roku do ZSRR jest wciąż naczelnym czynnikiem determinującym współczesna tożsamość piętnastu państw postradzieckich. Niewątpliwie jednak jest czynnikiem bardzo istotnym. Państwa byłego ZSRR są powiązane wieloma więziami politycznymi, gospodarczymi i kulturowymi. Trudno sobie też wyobrazić rozumienie procesów na współczesnym obszarze postradzieckim bez refleksji historycznej odwołującej się do przeszłości jeszcze odleglejszej niż radziecka. Tym bardziej, że we współczesnym nowym nie-porządku świata historia staje się niejednokrotnie narzędziem brutalnej polityki: historia bywa zaprzęgana w służbę polityki historycznej, która staje się po prostu narzędziem propagandy w konfliktach międzynarodowych. Mamy do czynienia z takimi zjawiskami jak: kwestionowanie historycznej legitymizacji państwowości sąsiadów, budowanie przywództwa w regionie w oparciu o twierdzenia o własnym cywilizacyjnym starszeństwie, przenoszenie współczesnych kategorii pojęciowych na odległą przeszłość, instrumentalne traktowanie historycznych tragedii (ludobójstw 
i innych masowych zbrodni), szermowanie pojęciem „prawdy historycznej”. $\mathrm{Z}$ tego także względu badania nad współczesnym obszarem postradzieckim wymagają umiejętnego posługiwania się teoretyczno-krytyczną refleksją wobec języka, jakim się o historii tego obszaru pisze i mówi.

Zaprezentowane $\mathrm{w}$ tomie artykuły młodych badaczy z różnych akademickich ośrodków Polski dotyczą w większości Rosji, Ukrainy i Białorusi. W XX wieku historyków rosyjskich i ukraińskich podzielił spór o dziedzictwo Rusi Kijowskiej, nota bene przez badaczy współczesnych odżegnujących się od narodowego paradygmatu uważany za bezpodstawny, o ile Ruś była wieloetnicznym imperium, konglomeratem wschodniosłowiańskim, ale z elementem skandynawskim i ugrofińskim, unifikowanym kulturowo przez język cerkiewnosłowiański. W Europie Wschodniej - na obszarze obecnej Ukrainy, Białorusi i Rosji - dochodziło do kontaktów różnych kręgów kulturowych: Zachodu (reprezentowanego m.in. przez Rzeczpospolitą Obojga Narodów), cywilizacji Wielkiego Stepu, islamu, świata śródziemnomorskiego. Od końca XVIII w. obszar Ukrainy, Białorusi i europejskiej Rosji był rdzeniową częścią Imperium Rosyjskiego. Wiek XX związał te kraje ideologią komunistyczną i stworzył z nich fundament Związku Radzieckiego. W ZSRR funkcjonowały jako oddzielne republiki o nazwach: Ukraińska Socjalistyczna Republika Radziecka, Białoruska Socjalistyczna Republika Radziecka, Rosyjska Federacyjna Socjalistyczna Republika Radziecka. Były to trzy z czterech republik założycielskich, a jednocześnie ich szczególny status sprawil, że to właśnie przywódcy tych trzech republik czuli się uprawnieni do podjęcia decyzji o rozwiązaniu ZSRR w 1991 roku.

Współcześnie są to państwa niepodległe od roku 1991, które od samego początku pozostają w silnych wzajemnych więziach na płaszczyźnie politycznej kulturowej, ekonomicznej i społecznej. Więzi te w znacznym stopniu mają wymiar zależności i relacji centrum-peryferie. Na przestrzeni lat ich wspólne stosunki się jednak zmieniały: Ukraina dystansowała się wobec projektów integracyjnych promowanych przez Rosję, a obecnie jest - w przekonaniu zdecydowanej większości społeczności międzynarodowej - ofiarą prowadzonej przez Rosję tak zwanej wojny hybrydowej. Białoruś natomiast w projektach takich uczestniczyła i nadal uczestniczy. Szczególną rolę w stosunkach tych trzech państw odgrywa język rosyjski: ma on status drugiego języka oficjalnego w Republice Białoruś, 
zaś na Ukrainie ma - dyskusyjny i kontrowersyjny - status języka regionalnego na niektórych obszarach, pozostając jednocześnie powszechnym językiem komunikacji społecznej.

Oprócz tekstów poświęconych ściśle Rosji, Białorusi i Ukrainie, znajdujemy tu także publikacje poświęconą cyberterroryzmowi w globalizującym się świecie (co koresponduje z częścią tego numeru poświęconą fenomenowi Gwiezdnych Wojen) oraz tekst o islamskim ekstremizmie w Azji Środkowej - który to fenomen ma też transnarodowy, transgraniczny i nowoczesny charakter. 